The Historical Journal, 64, 1 (2021), pp. 121-138 (C) The Author(s), 2020. Published by Cambridge University Press. This is an Open Access article, distributed under the terms of the Creative Commons Attribution-NonCommercial-NoDerivatives licence (http://creativecommons.org/ licenses/by-nc-nd/4.0/), which permits non-commercial re-use, distribution, and reproduction in any medium, provided the original work is unaltered and is properly cited. The written permission of Cambridge University Press must be obtained for commercial re-use or in order to create a derivative work.

doi:10.1017/Soo18246X1900o621

\title{
UTOPIA/WUTUOBANG AS A TRAVELLING MARKER OF TIME*
}

\author{
LORENZO ANDOLFATTO \\ Heidelberg University
}

ABSTRACT. This article argues for the understanding of 'utopia' as a cultural marker whose appearance in history is functional to the a posteriori chronologization (or typification) of historical time. I develop this argument via a comparative analysis of utopia between China and Europe. Utopia is a marker of modernity: the coinage of the word wutuobang ('utopia') in Chinese around I 895 is analogous and complementary to More's invention of Utopia in ${ }_{15} \mathrm{I} 6$, in that both represent attempts at the conceptualizations of displaced imaginaries, encounters with radical forms of othernessthe European 'discovery' of the 'New World' during the Renaissance on the one hand, and early modern China's own 'Westphalian' refashioning on the other. In fact, a steady stream of utopian conjecturing seems to mark the latter: from the Taiping Heavenly Kingdom borne out of the Opium wars, via the utopian tendencies of late Qing fiction in the works of literati such as Li Ruzhen, Biheguan Zhuren, Lu Shi'e, Wu Jianren, Xiaoran Yusheng, and Xu Zhiyan, to the reformer Kang Youwei's monumental treatise Datong shu. Altogether, these sketches of utopia provide an imaginary counterpoint to the co-produced regimes of historicity whose genealogies are being traced in this issue.

For it did not occur to us to ask, nor to him to say, in which part of the New World Utopia is to be found ...

(Thomas More, Utopia)

We sailed from Peru ... for China and Japan ...

(Francis Bacon, New Atlantis)

Heidelberg University, Heidelberg Centre for Transcultural Studies, Voßstr. 2, Building 44oo, 69I I 5 Heidelberg, Germany lorenzo.andolfatto@hcts.uni-heidelberg.de

* Research for this project has received funding from the European Union's Horizon 2020 research and innovation programme under grant agreement no. 649307. I also gratefully acknowledge the generosity of the Chiang Ching-kuo Foundation for International Scholarly Exchange, without whose support for my research project, 'The three faces of Utopianism revisited (once again)' (grant no.: PDo14-U-1 8) at Heidelberg University's Centre for Asian and Transcultural Studies, the present study could not have been completed. 
This is an exercise in comparative literature that is informed by recent debates in the theory and philosophy of historiography. The comparative aspect of this study not only refers to its subject matter - the production of utopian discourses in Europe and China at crucial times in history - but also to the methods of the narrative domains at stake - that of literature, and that of history writing. Such a perspective, one that addresses matters of historiographical enquiry from the standpoint of literature, subscribes to Hayden White's understanding of historical narratives as 'verbal fictions', ' but interrogates one of their constitutive devices: the chronotype. ${ }^{2}$ I thus engage with the notion of chronotype by folding it back onto its literary model (the Bakhtinian chronotope) via the notion of genre. In doing so, my goal is twofold. On the one hand, I intend to foreground chronotypes as ambivalent constructs that, while effectively making up what they address (e.g. 'The Renaissance'), at the same time allow for its co-productive interplay (e.g. 'renaissance' as a historiographical category deployed by different agents). On the other, I intend to highlight how the functional equivalence between the writing of history and the writing of literature allows for the literary text to work as a marker of historical time.

A peculiar idiosyncrasy marked the appearance of the word 'utopia' in Chinese. Echoing utopia's playful etymology, the calque wutuobang 烏托邦 entered the Chinese lexicon as an empty signifier: it pointed at something that was not there. Coined by the late Qing scholar and translator Yan Fu 嚴復 $\left(1854^{-1921)}\right.$ in his translation of Thomas H. Huxley's Evolution and ethics of 1894-5, wutuobang had no direct equivalent in Huxley's source text, in that nowhere in Evolution and ethics is the word 'utopia' used. Yan Fu deployed the neologism wutuobang as the title of one of the fifteen prolegomena that Huxley added to the 1894 edition of his original lecture from $1893 .{ }^{3}$ In the sixth of these prolegomena, Huxley restates his argument for humanity's emancipation from the laws of Darwinian evolution by means of a metaphor: similarly to the way a properly managed garden can shield its plants from the struggle for survival in the natural world, so humanity can emancipate itself from the 'state of nature' via the establishment of properly administered 'colonies'. The ideal goal of

${ }^{1}$ Hayden White, Topics of discourse: essays in cultural criticism (Baltimore, MD, and London, $1978)$, p. 82 .

${ }^{2}$ See John Bender and David Wellbery, eds., Chronotypes: the construction of time (Stanford, CA, 1991), and below.

3 Tianyan lun 天演論 as a whole provides a peculiar example of Yan Fu's 嚴復 peculiar modus traducendi. On Yan Fu, see Benjamin I. Schwartz, In search of wealth and power: Yen Fu and the West (Cambridge, MA, 1964); on his translation method, see David Wright, 'Yan Fu and the task of the translator', in Michael Lackner, Iwo Amelung, and Joachim Kurtz, eds., New terms for new ideas: Western knowledge and lexical change in late imperial China (Leiden, 2001), pp. 235-56; on the translation of Evolution and ethics in particular, see Tian Modi 田默迪, 'Yan Fu Tianyan lun de fanyi zhi yanjiu yu jiantao: yu Hexuli yuanwen zhi duizhao bijiao' 嚴復天演論的翻譯 之研究與檢討: 與赫胥黎原文之對照比較 (“A study of Yan Fu's translation of The theory of natural evolution: a comparison of it with Huxley's original text'), Zhexue yu wenhua, 19 (1975), pp. $4^{-18}$. 
humanity, Huxley concludes, would therefore be 'the establishment of an earthly paradise, a true garden of Eden, in which all things should work together towards the well-being of the gardeners'. 4 In his translation titled Tianyan lun 天演論 (The theory of natural evolution), Yan Fu then glossed Huxley's 'garden of Eden' by adding that 'the Chinese call this Huaxu 華胥 [Land of dreams5'], while the Westerners call it wutuobang' ${ }^{6}$

Yan Fu was among the first late Qing literati to study abroad - 'Great Britain was to become his ideal model, and English ideas were to dominate his intellectual development'7 - and therefore his familiarity with the English language and literary tradition should not come as a surprise. Yet because Thomas More's Utopia would not make its appearance in Chinese until much laterwith Liu Linsheng's 劉麟生 1935 translation-Yan's choice of words in Tianyan lun remains remarkable. ${ }^{8}$ Why did he decide to coin a specific, hitherto unused neologism in order to elucidate an image - the garden as colony/ enclave - that was in itself quite self-explanatory? Furthermore, wenyan 文言, that is to say the variety of literary Chinese used by Yan Fu in his translation, already offered a meaningful array of lexical choices that could better approximate Huxley's botanical metaphor: from the biblical leyuan 樂園 ('garden of delights' or 'earthly paradise') and yidian yuan 伊甸園 ('garden of Eden'),9 and the Buddhist jingtu 净土 (the 'Pure Land' of Amidism), to the autochthonous letu 樂土 ('happy land') and leguo 樂國 ('happy state') used as early as in the

4 Thomas H. Huxley, Evolution and ethics and other essays (New York, NY, 1896), p. 19.

5 In Liezi列子, a Daoist text traditionally attributed to Lie Yukou 列禦寇 (approximately fifth century BCE) but most likely compiled around the fourth century CE, Huaxu is described as a country where 'there are no teachers and leaders; all things follow their natural course' (國無師長, 自然而已). Translation by A. C. Graham in The book of Lieh-tzu (New York, NY, $1990)$, p. 34 .

6 ‘中國謂之曰華胥, 而西人稱之曰烏托邦’. Tianyan lun 天演論, in Wang Qingcheng 王慶成, ed., Yan Fu heji 嚴復合集 (The collected works of Yan Fu) (20 vols., Taipei, 1998), viI, p. 14. Interestingly, in a later revision from 1897, Yan excised the gloss's first half, opting for 'wutuobang' as his final translation choice (compare the 'Weijing' 味經 version of Tianyan lun from 1895 in Wang, Yan Fu heji, p. 14, with the 'Shougao' 手稿 version from 1898 in ibid., p. 10o).

7 Schwartz, In search of wealth, p. 27.

8 See Yan Jianfu 顏健富, Cong 'shenti' dao 'shijie': Wan Qing xiaoshuo xin gainian ditu 從「身體」到「世界」：晚清小說新概念地圖 (From 'body' to 'world': the new conceptual map of the late Qing novel) (Taipei, 2014), p. 143. One could also argue that the unnecessary addition of an unfamiliar neologism to a wenyan rendition of Evolution and ethics would hardly adhere to Yan Fu's own stylistic principles of xin 信 (faithfulness), da 達 (comprehensibility), and ya 雅 (elegance). See Yan Fu, 'Preface to Tianyan lun (1901)', trans. C. Y. $\mathrm{Hsu}$ in Leo Tak-hung Chan, Twentieth-century Chinese translation theory: modes, issues, and debates (Amsterdam, 2004), pp. 67-71.

9 Systematic translations of the Bible began to appear in China some ninety years prior to Yan Fu's beginnings as a translator. See Chloë Starr, Reading Christian scriptures in China (London, 2008), pp. 32-48. On the usage of leyuan 樂園 in particular, see Zheng Haijuan 鄭海娟, 'Wenben zhi wang: Gu xin Shengjing yu qianhou dai Shengjing Hanyi ben zhi guanxi’ 文本之網: 《古新聖經》與前後代《聖經》漢譯本之關係 ('The relationship between Poirot's Chinese Bible and Chinese translations of the Bible made before and after it'), Qinghua zhongwen xuebao, 11 (2014), pp. 261-98, at pp. 281-2. 
Shijing 詩經 (Classic of Poetry, eleventh to seventh century вСЕ), ${ }^{10}$ the Confucian datong 大同 ('great harmony') and xiaokang 小康 ('small tranquillity'), and the Daoist taiping 太平 ('great peace'), ${ }^{11}$ if not classical China's very own utopian archetype, taohua yuan 桃花源 ('Peach Blossom Spring'). ${ }^{12}$ The sudden emergence of wutuobang as utopia from the sea of Chinese lexicon towards the end of the nineteenth century seems rather to suggest that this word fulfilled a particular cultural need at a precise moment in Chinese history.

The recoinage of autochthonous taohua yuan as wutuobang in early modern China, though on the surface an individual translator's quirk, calls for the reevaluation of utopia in light of its transcultural circulation. On the one hand, the reasons for utopia's transcultural reframing are embedded in the idea itself: whether it be qualified as Platonic Politeia, Confucian datong, Daoist taohua yuan, or Morean Nusquama, utopia demands a leap of imagination beyond the limits of one's own culture and towards the nowhere-else that it posits. On the other, as this article tries to demonstrate, utopianism as a modality of thinking and practice seems to surface with substantially similar features 'through all the provinces of history' at certain crucial times. ${ }^{13}$ Yet because, as Quentin Skinner warns, setting out the 'ideal type' of any given notion would risk hypostatizing it into a 'fully developed form ... always in some sense immanent in history', and because the idea of utopia already posits in itself an ideal type of sorts - utopia is by self-definition immanent in historyits transcultural recurrence must be contextualized. ${ }^{14}$

In doing so, I do not intend to draw an alternative genealogy of this idea nor to trace the branching out of 'utopia' from its presumed classical loci of coinage to its reverberations in conveniently distant contexts. ${ }^{15}$ Rather, I want to argue for the emergence of utopian thinking (expressed in writing and practice) as the cultural inflorescence of particular socio-historical conditions coming together in a given time and place: in other words, how the imaginary institution

${ }^{10}$ Namely in the ode titled 'Shuo shu' 碩鼠 ('Large rats') under the Weifeng 魏風 (Odes of Wei) section of the collection.

${ }^{11}$ In light of the Taiping Rebellion (Taiping tianguo yundong 太平天國運動; literally, 'Taiping Heavenly Kingdom Movement'), which ravaged the country from 185 o to 1864 , this choice could in fact have burdened the text with implications that were perhaps too problematic.

12 Taohua yuan in particular, electing the image of a secluded garden as metonymy for perfect society, would have actually made for the most coherent (that is, source-oriented as well as target-oriented) rendition of Huxley's passage. See Longxi Zhang, 'Tao Qian, the idea of garden as home, and the utopian vision', International Communication of Chinese Culture, 3 (2016), pp. $365^{-75}$; and below.

13 Arthur J. Lovejoy quoted in Quentin Skinner, 'Meaning and understanding in the history of ideas', History and Theory, 8 (1969), pp. 3-53, at p. 10.

14 Ibid.

15 'It is not sufficient to imagine a simple binary opposition between dominant and dominated literary spaces. One would do better to speak of a continuum, for the many forms of antagonism to which domination gives rise prevent a linear hierarchy from establishing itself.' Pascale Casanova, The world republic of letters (Cambridge, MA, 2004), p. 83. 
of utopia responds to similar structural stimuli. ${ }^{16}$ By considering the emergence of utopian thinking as the by-product of (relatively) commensurable historical situations, my goal is to avoid the two main fallacies at stake when drafting the history of an idea: namely, its reduction to the matter of the text in which it first appears (for example, 'utopia' as something that is inextricably bound to the blueprint of Thomas More's book); and, conversely, its univocal ascription to the local context from which it emerges (for example, utopia as a unique byproduct of the historical context of early Renaissance England $\left.{ }^{17}\right) .{ }^{18}$ The local production of utopias may tap into autochthonous tropes and motives, ${ }^{19}$ or adapt blueprints received from abroad, ${ }^{20}$ yet these traits remain accessory. Analogous historical contexts engender similar imaginary practices, so that a certain context may provide the ground for a certain kind of abstraction in very much the same way (to rehash Huxley's metaphor) that a given terrain will sustain the production of certain plants better than others.

In order to demonstrate this point, I will attempt a comparison between two apparently distant cultural contexts in which the idea of utopia gained similarly unprecedented traction: early sixteenth-century England and late nineteenthcentury China. ${ }^{21}$ Insofar as "[g]enres provide a conceptual framework for the mediation (if not the "solution") of intractable problems, a method of rendering such problems intelligible', narrative utopias came about in these contexts to mediate specific problems generated by hitherto unprecedented historical circumstances. ${ }^{22}$ What made the actors inhabiting these cultural contexts particularly receptive towards the fashioning of 'inverted images' and 'notions of nowhere' from which to look back at their own present was a radical shift in their understanding of space and time. ${ }^{23}$ In the case of early sixteenthcentury England, preconceived understandings of space and time were thrown off by the growing awareness of there being a mundus novus expanding

16 'Imaginary: an unmotivated creation that exists only in and through the positing of images.' Cornelius Castoriadis, The imaginary institution of society (Malden, MA, 1987), p. 247.

${ }^{17}$ Focusing on More's use of language, Wayne A. Rebhorn argued, for example, 'that the Utopia can be read as a brilliant articulation of humanist ideals of education in the tradition of Erasmus'. See 'Thomas More's enclosed garden: “Utopia” and Renaissance humanism', English Literary Renaissance, 6 (1976), p. 149.

18 Skinner, 'Meaning and understanding', p. 3.

19 E.g. Li Ruzhen's 李汝珍 (c. 1763-1830) rehashing of traditional motives in the novel Jinghuayuan 鏡花緣 (Flowers in the mirror, 1827); Li Ruqian's 黎汝謙 (1852-19og) rewriting of Zhuangzi's 'Zigzag country' passage in Weileiguo youji 畏壘國游記 (Record of a trip to the country of Zigzag, c. 1898); or Biheguan Zhuren's 碧荷館主人 adaptation of the Peach Blossom Spring trope in the novel Huangjin shijie 黃金世界 (The golden world, 1906).

${ }^{20}$ E.g. the wave of miraiki/weilaiji 未來記 ('future records') novels that the translation of Edward Bellamy's Looking backward: 2000-I887 inspired in fin de siècle China. See Catherine Vance Yeh, The Chinese political novel: migrations of a world genre (Cambridge, MA, 2015).

21 Douwe Fokkema argues along similar lines in his book Perfect worlds: utopian fiction between China and the West (Amsterdam, 2011).

22 Michael McKeon, Origins of the English novel, I6oo-I74o (Baltimore, MD, 1987), p. 20.

23 Paul Ricoeur, Lectures on ideology and utopia (New York, NY, 1986), pp. 4, 15. 
beyond existing geographical, political, and cultural cartographies. In the case of late imperial China, foreign intervention threw off the last tenets of a Sinocentric worldview that organized tianxia 天下 ('all under heaven') in terms of dependency on the imperial court, along with culturalist dichotomies that framed as 'barbarian' ( $y i$ 夷) what lay beyond China proper. ${ }^{24}$ These were events of global significance, whose importance was marked in both cases by the appearance of very specific ways of writing about time and space.

The writing of narrative utopias during these crucial junctures performed a buffering function, elaborating through the allegory of the literary text the impact and uncertainty brought forward by the changing of global co-ordinates. Written in Latin in $15^{16}$ and first translated in English in 1551, More's Utopia punctuated the long sedentary hiatus between John Cabot's last overseas expedition (in 1497) and Francis Drake's first voyage (in 1577), addressing by extension 'the apparent slowness of Europe in making the mental adjustments required to incorporate America within its field of vision'. ${ }^{25}$ Similarly, the flourishing of wutuobang narrations in late imperial China, following in particular the Wuxu bianfa 戊戌變法 ('Hundred Days' Reform') debacle of 1898, punctuated late imperial China's slowness in coming to terms with the new ('Westphalian') world. ${ }^{26}$ In both cases, the writing of utopias marked a moment of cautionary retrenchment and epistemological re-elaboration: of the Tudor court against Spain and Portugal's dominant position in the Atlantic trade between 1492 and circa $1570 ; 27$ and of the Manchu court's condition of (semi-)colonial subjugation against the expanding presence of the West in East Asia during the second half of the nineteenth century.

For the sake of this argument, it is useful here to consider utopia, as both an idea and a literary genre, in the guise of a 'chronotype'. Building upon Mikhail Bakhtin's notion of 'chronotope' as 'the intrinsic connectedness of temporal and spatial relationships' of a literary text, John Bender and David E. Wellbery posited chronotypes 'as models or patterns through which time

${ }^{24}$ See Wang Ermin 王爾敏, “'Zhongguo” mingcheng suyuan ji qi jindai quanshi’「中國」 名稱溯源及其近代詮釋 ('On the etymology of Zhongguo and its interpretations in the early modern period'), in Wang Ermin, Zhongguo jindai sixiang shilun 中國近代思想史論 (A study of late Qing political thought) (Taipei, 1995; orig. edn 1969), pp. 447-86.

25 John H. Elliott, The old world and the new, I492-I650 (Cambridge, 1970), p. 8. On the English translations of More's Utopia, see Elizabeth McCutcheon's review essay, 'Ten English translations/editions of Thomas More's Utopia', Utopian Studies, 3 (1992), pp. 102-20, at p. 104 .

${ }^{26}$ See Lorenzo Andolfatto, Hundred Days' literature: Chinese utopian fiction at the end of empire, I902-I9Io (Leiden, 2019).

${ }^{27}$ 'When in 1585 a forlorn little band of Englishmen were trying to stick it out on Roanoke Island, three hundred poets were competing for a prize in Mexico City.' Howard Mumford Jones, O strange new world: American culture, the formative years (New York, NY, 1964), p. 85. See also Lyle N. McAlyster, Spain and Portugal in the New World, I492-I7oo (Minneapolis, MN, 1984), pp. 74-107. 
assumes practical or conceptual significance'. ${ }^{28}$ Chronotypes are markers of temporality; they provide unifying directives for the inscription of particular historical contingencies into larger explanatory frameworks (such as the ideas of 'Reformation', 'Enlightenment', 'Renaissance', the Italian Risorgimento, or the German Wiedergeburt). Utopia, then, is akin to the notions of chronotype and chronotope in that it provides an ideal image of the 'intrinsic connectedness' of time and space through and in the literary text. 'Utopia was born with modernity', Krishan Kumar remarks about More's eponymous work; ${ }^{29}$ similarly, late imperial China's compelled modernization starting from the First Opium War gave rise to new strands of utopian-like imaginaries that transposed in figurative terms the country's 'need for a thorough reappraisal of her position vis-à-vis the outside world in general and the West in particular'.$^{\circ}$

What qualifies the utopian chronotope as a marker of historical time is the twofold relationship, at the same time analogical and contrapuntal, that links the practice of writing utopia to the writing of history. Building upon Frank R. Ankersmit's thesis that ' $[\mathrm{h}]$ istoriography develops narrative interpretations of sociohistorical reality; literature applies them', we may argue that utopian literature develops narrative interpretations of socio-historical reality via the latter's radical negation, especially when the said reality is undergoing substantial changes in the way in which it understands itself in time and space. ${ }^{31}$ As Kumar further remarks, '[u]topia ... expels history from its timeless order of perfection', yet behind this apparent gesture of expulsion is an act of 'chronotypic' foregrounding - the recognition of the limits of pre-existing epistemological co-ordinates for making sense of time and space. ${ }^{32}$ New calendars and new maps always accompany the writing of utopias: born out of critical shifts in the understanding of time and space, "utopias dramatize historical crisis ... [and] show how history is made up - in the double sense of "constituted" and "fictionalized" - in order to show how it can be made over'.33

Yet it is not only by virtue of utopia's contrapuntal relation with history that the writing of utopia is akin to the writing of history. These practices are predicated upon similar rhetorical strategies, in that both the utopian and the historiographical text are the results of constructivist operations of colligation "which [bring] a number of empirical "facts" together by "superinducing" upon them a conception that integrates and makes them in this way capable

${ }_{28}$ Mikhail Bakhtin, 'Forms of time and of the chronotope in the novel', in The dialogic imagination (Austin, TX, and London, 1981), p. 84; Bender and Wellbery, eds., Chronotypes, p. 4 .

${ }^{29}$ Krishan Kumar, Utopianism (Minneapolis, MN, 1991), p. $5^{1}$.

$3^{\circ}$ Fred W. Drake, China charts the world: Hsu Chi-yü and his geography of ${ }_{1} 848$ (Cambridge, MA, 1975), p. 53 .

$3^{1}$ Frank R. Ankersmit, History and tropology: the rise and fall of metaphor (Berkeley, CA, and London, 1991), p. 34.

$3^{2}$ Kumar, Utopianism, p. 44.

33 Marina Leslie, Renaissance utopias and the problem of history (Ithaca, NY, 1998), p. 8. 
of being expressed by a general law'.34 By way of comparison, if the 'general law' of the Renaissance as a historiographical construct is broadly defined by the 'creation of states as merely political structures regardless of moral norms', 'the development of the individual', and the '[d] iscovery of world [in relation to] man',35 or the law of the Enlightenment is the prevalence of 'reason' over other modalities of thought, then the general law of utopia is its being the best of the possible worlds yet to be realized.

Before delving further into the analysis of utopian representations between China and Europe, a working definition of utopia as a practice of imaginary colligation is in order here. In its broadest sense, utopia is 'the imaginary projection of a society that is substantially different from the one in which the author lives'. ${ }^{6}$ Throughout history, this imaginary projection has been developed in many forms: as Lyman Tower Sargent remarks, a comprehensive account of this idea would have to include utopian traditions in literature, social experiments informed by utopian ideals, and utopian social theory. 37 Fatima Vieira further highlights the following most commonly recurring aspects of this construct in literature: (1) the oppositional character of utopia's 'ideology'namely, the presentation of an ideal society predicated upon the rejection of the ideological tenets of the socio-historical reality whence it originates; (2) its literary form - that is, the prevalence of exposition over narration, the philosophical digressions, the spatio-temporal displacement, and so forth; (3) its function - the expected impact of utopia on the reader's mind; and ultimately (4) the 'principle of hope' that underlies it - what Ernst Bloch defined as 'hoping beyond the day which has become'. $3^{8}$ For practical reasons, I will rely here on the operational definition given by the science fiction scholar Darko Suvin in Metamorphoses of science fiction: 'Utopia is the verbal construction of a particular quasi-human community where sociopolitical institutions, norms and individual relationships are organized according to a more perfect principle than in the author's community, this construction being based on estrangement arising out of an alternative historical hypothesis.' 39

${ }^{34}$ Jouni-Matti Kuukkanen, Postnarrativist philosophy of historiography (Basingstoke, 2015), p. 99 .

35 Thomas Maissen and Barbara Mittler, Why China did not have a Renaissance - and why that matters (Berlin, 2018), p. 55 and passim. See also Pablo Blitstein's essay in this special issue.

$3^{36}$ Gregory Claeys and Lyman Tower Sargent, The utopia reader (New York, NY, 1999), p. 1.

37 Lyman Tower Sargent, 'Three faces of utopianism revisited', Utopian Studies 5, no. 1 (1994), p. 4. It is worth noting that, for what concerns Chinese utopianism, all these 'three faces' emerge during the second half of the nineteenth century: in literature, with the inflorescence of utopian novels; as social experiment, chiefly with the Taiping Rebellion and its ideal of Taiping tianguo 太平天國; and as social theory, with Kang Youwei’s 康有為 political project delineated in Datong shu 大同書 (The book of great harmony).

$3^{8}$ Ernst Bloch, The principle of hope (Cambridge, 1986), p. 10. Fatima Vieira, 'The concept of utopia', in Gregory Claeys, ed., The Cambridge companion to utopian literature (Cambridge, 2010), pp. $3^{-27}$, at pp. $6-7$.

39 Darko Suvin, Metamorphoses of science fiction (New Haven, CT, and London, 1979), p. 49. I am aware that these definitions, formulated by Western scholars referring to conventionally 
Within the European literary tradition, the archetype of utopia is to be found in Thomas More's (1478-1535) eponymous work, De optimo rei publicae statu deque nova insula Utopia (On the best state of a commonwealth and on the island of Utopia), published in $15^{16}$ in Leuven. $4^{\circ}$ More probably conceived the idea of 'utopia' in the summer of $15^{1} 5$, during an embassy to Bruges as a representative of England's royal trade commission. During his stay in Flanders he visited Antwerp, where he met Peter Giles (Pieter Gillis, 1486-1533), a fellow scholar, civil servant, and (like More) intimate of Erasmus of Rotterdam (1466-1536). Utopia, composed of two parts, reflects these experiences: book I begins with a brief account of More's diplomatic mission and of his acquaintance with Giles, whose fictionalized persona, together with the eclectic figure of Raphael Hythloday, takes the centre stage in a fictional conversation with More on the morality and legitimacy of providing counsel to a prince. Book II, on the other hand, consists of Hythloday's account of the 'Island of the Utopians' and the perfect features of its government and society. '[Y] ou should have been with me in Utopia and seen with your own eyes their manners and customs ...', Hythloday tells More and Giles at the end of book I; '[if] you had seen them, you would frankly confess that you had never seen a well-governed people anywhere but there' $.4^{1}$

More initially conceived Utopia's book II as a stand-alone fictional travelogue narrated by Hythloday after his alleged return from Amerigo Vespucci's third voyage to the New World. $4^{2}$ Yet even though the matter of book I, together with Utopia's ancillary correspondence, was composed later, the twofold structure of the work's final edition came to embody the underlying principle at its core. When Thomas More conceived the island of the Utopians in $15^{16}$, he most likely had in mind the geography of the British Isles: his description at the beginning of book II- 'two hundred miles across in the middle part,

\footnotetext{
'Western' corpora, may be problematic to deploy comparatively. At the same time, I cannot deny the point of origin of my argument - a reflection on the word 'utopia' and its translation. Tentatively, I argue here that these parameters simply work for circumscribing a coherent transcultural corpus of texts that one side would call 'utopian' and the other taohua yuan- or datonglike.

$4^{\circ}$ For a comprehensive account of Utopia's composition, see Jack H. Hexter, More's Utopia: the biography of an idea (London, 1952), and the critical apparatus of Edward Surtz S.J. and Jack H. Hexter, eds., The Yale edition of the complete works of St Thomas More: volume 4, Utopia (New Haven, CT, and London, 1965).

${ }^{11}$ Thomas More, Utopia, ed. George M. Logan and Robert M. Adams (Cambridge, 2002), p. 39 .

$4^{2}$ The question of the reliability of Amerigo Vespucci's diaries seems to be a highly divisive issue among historians. Whether the accounts that were attributed to Vespucci at the turn of the sixteenth century were false (according to Alberto Magnaghi's philological critique of Vespucci's papers as discussed in Frederick J. Pohl, Amerigo Vespucci: pilot major (New York, NY, 1944)) or true (as per the rebuttal in German Arciniegas, Amerigo and the New World: the life and times of Amerigo Vespucci (New York, NY, 1955)), they nevertheless provided inspiration for More's fictional travelogue. In fact, it may very well be the case that the unreliability of these early accounts prompted More to write one in the same vein.
} 
where it is widest, and nowhere much narrower than this except towards the two ends ... crescent-shaped, like a new moon'43-borrowed from 'The Descripcyon of Englonde' included in The St Albans chronicle by Thomas Walsingham (d. c. 1422).44 Yet it was not Utopia's resemblance to the reality of sixteenth-century England that granted this work recognition, but rather the radical potential of its idea. As the etymology of the word itself suggests, the imagination of utopia requires a gesture of negation and displacement from the contingent reality of the author and the imaginary of radical difference represented by the utopian locus 45 -an engagement, as Antonis Balasopoulos terms it, with 'spatial disjunction' and 'political deterritorialization' $.4^{6}$

On the level of form, this disjunction is emphasized by the difference between the dialogical and oratory style of book $\mathrm{I}-\mathrm{a}$ well-recognized format in the humanist tradition of More - and the travelogue presented in book II. $47 \mathrm{On}$ the figurative level of the text, the positing of the hiatus is conveyed by the image of Utopia's transformation into an island upon King Utopus's decision to have 'a channel cut fifteen miles wide where the land joined the continent, [which] thus caused the sea to flow around the country'. $4^{8}$ As Fredric Jameson argues by building on Louis Marin's semiotic analysis of More's book, such a symbolic gesture maintains a double edge, in that it reasserts (rather than severing) the link between utopia and the present, allowing for the former's 'superimposition' onto the latter (i.e. utopia replaces the present), but also for the

43 More, Utopia, p. $4^{1}$.

44 Brian R. Goodey, 'Mapping "Utopia”: a comment on the geography of Sir Thomas More', Geographical Review, 6o (1970), pp. $15^{-3}$ o, at p. 19. Incidentally, '[c]rescent-shaped, like a new moon' is a fitting description of the British Isles as portrayed in the Anglo-Saxon Mappa Mundi, created in Canterbury between 1025 and $105^{\circ}$.

45 See, e.g., Richard Helgerson, 'Inventing noplace, or the power of negative thinking', in Stephen Greenblatt, ed., The power of forms in the English Renaissance (Norman, OK, 1982), pp. 101-22.

$4^{6}$ Antonis Balasopoulos, "'Suffer a sea change": spatial crisis, maritime modernity, and the politics of utopia', Cultural Critique, 63 (2006), pp. $123^{-5} 5^{6}$, at pp. 127,124 .

47 Ultimately, what links the two books is Utopia's overall seriocomic mode-More's proclivity toward serio ludere ('to play seriously'), making serious point in the guise of jokes, witticisms, mock orations, and absurd scenarios, which found in the works of Lucian and Apuleius its loci classici, and in Erasmus's Praise of folly its most poignant example. Utopia's best-known feature, its titular wordplay, is but the most evident marker of the text's underlying satirical verve. The word 'utopia' comes from the juxtaposition of the Greek prefix ov' ('ou': no) and the noun

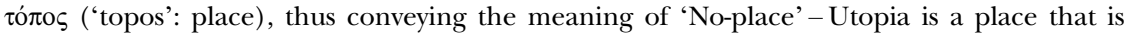
not a place. The name Hythloday/Hythlodaeus derives from the Greek words $0 \theta_{0} \varsigma$


be translated as 'experienced in' but also 'hostile to nonsense'; 'Anyder', the island's main river, comes from the Greek word v̋ $\omega \rho$ ('ydor': water) preceded by the prefix $\alpha$ - ('a-') expressing negation, and is thus 'a river without water'; the 'Nephelogetes', who are allies of the Utopians, are people 'generated' (from the Greek suffix - $\gamma \varepsilon v \eta ́ \varsigma$ (-genes)) 'from the clouds' (vé $\varphi$ os (nephos)); etc. On Utopia as a 'jeu d'esprit', see also Edward Surtz S.J., 'Interpretations of Utopia', Catholic Historical Review, 38 (1952), pp. 156-74.

$4^{8}$ More, Utopia, p. $4^{2}$. 
latter's historical 'emplacement' (i.e. the present is historicized, it is recognized in and as history).49 It is upon the utopian text's covert function of historical emplacement of the real via its overt displacement and apparent negation, rather than in the fanciful depictions of imaginary landscapes and exotic populations, that the utopian chronotope effectively translates and functions as a marker of historical time.

A similar gesture of disjunction (but not yet of emplacement) can be found at the core of what is considered the locus classicus of utopian fiction within the canon of classical Chinese literature: Tao Yuanming's 陶淵明 fable Taohua yuan ji 桃花源記 (The story of the Peach Blossom Spring). $5^{\circ}$ Written in 421 CE at the beginning of the Nan-Bei chao 南北朝 ('Northern and southern dynasties') period, an interval of institutional fragmentation and political chaos that followed the demise of the Jin 晉 empire in 420, Taohua yuan ji tells the story of a fisherman's fortuitous discovery of a reclusive community inside a remote grotto located at the heart of a peach-tree forest:

Imposing buildings stood among rich fields and pleasant ponds all set with mulberry and willow. Linking paths led everywhere, and the fowls and dogs of one farm could be heard from the next. People were coming and going and working in the fields. Both the men and the women dressed in exactly the same manner as people outside; white-haired elders and tufted children alike were cheerful and contented. $5^{1}$

Yet while it is true that Tao Yuanming's Taohua yuan ji offers one of the earliest fictional formulations of the utopian chronotope, its comparison with More's Utopia is relatively sterile. Taohua yuan ji and Utopia vastly differ at the level of their formal features: Tao Yuanming's utopian fable, even when considered together with the poem 'Taohua yuan shi' 桃花源詩 ('Ode to the Peach Blossom Spring') with which it is usually paired, does not exceed 5 oo characters (322 in prose and 160 in verse). Translated in its entirety, it would not surpass the length of the shortest of the letters that introduce the main body of More's Utopia. Though word count is seldom relevant in the evaluation of the quality of a piece of literature, Taohua yuan jis conciseness, its standard stylistic features, and its canonical references to Daoism do not suggest the intention, on the part

49 Fredric Jameson, 'Of islands and trenches: naturalization and the production of utopian discourse', Diacritics, 7 (1977), pp. 2-21, at pp. 7-8; see also the first chapter of Louis Marin, Utopiques: jeux d'espaces (Paris, 1973), on utopia's 'neutre pluriel' ('plural neutrality' as per Robert A. Vollrath's translation).

$5^{\circ}$ Fokkema, Perfect worlds, p. 165; and Zhang, 'Tao Qian', p. 366 . On the reception of Tao Yuanming's work, see Wendy Swartz, Reading Tao Yuanming: shifting paradigms of historical reception (427-I90o) (Cambridge, MA, 2008).

$5^{1}$ '土地平曠, 屋舍儼然。有良田、美池、桑竹之屬。阶陌交通, 雞犬相聞。其中往來種作, 男女衣著, 悉如外人。黃髮垂髺, 並怡然自樂, Tao Yuanming, Taohua yuan ji 桃花源記, in Tao Qian 陶潛 and Gong Bin 竟斌, eds., Tao Yuanming ji xiaojian 陶淵明集校箋 (The collected writings of Tao Yuanming) (Shanghai, 2011 ), p. 425; translated in Cyril Birch, ed., Anthology of Chinese literature, volume I: from early times to the fourteenth century (New York, NY, 1965), pp. 167-8. 
of Tao Yuanming, to engage in any kind of radical or oppositional literary project.

In fact, the utopian imaginary delineated by Tao Yuanming was not one of radical difference, but rather of nostalgia; it posited no opposition to the prevailing ideology. Written in a time of political upheaval and instability - that is, the long period of political fragmentation that followed the fall of the Han 漢 (206 вCE-220 CE) and lasted until the Sui 隋 reunification in 581-Taohua yuan ji reads like a nostalgic vision of the past. The Peach Blossom Spring is presented as a pastoral haven that was spared from history's ruinous unfolding:

For their part they told how their forefathers, fleeing from the troubles of the age of Ch'in [Qin 秦, 221-206 BCE], had come with their wives and neighbours to this isolated place, never to leave it. From that time on they had been cut off from the outside world. They asked what age was this: they had never even heard of the Han, let alone its successors the Wei and the Chin [Jin]. $5^{2}$

Even though Tao Yuanming's 'cutting off' of the Peach Blossom Spring 'from the outside world' may recall More's severing of the island of Utopia from the continent, the 'nowhere-elses' that these texts posit remain meaningfully different. In Tao Yuanming's fable, history is not emplaced/transcended but rather forgotten, as if it had never happened.

Tao Yuanming's instance of historical 'withdrawal' in Taohua yuan ji was coherent with the aesthetics of its time. As Zongqi Cai suggests, owing to the fragile political context of the time, which highly inhibited intellectual pursuit and the literati's participation in public discourse, the aesthetics of the Six Dynasties $(222-589 \mathrm{CE})$ developed as one of disengagement and retreat from public fora to private enclosures - mingshi 名士 ('famous scholars') coteries, private patrons' gardens, and the salons of aristocratic families. 53 As the intellectual debate shifted from public to private, its tenor became more abstract and 'abstruse'.54 Taohua yuan ji is a by-product of the aesthetic of disengagement that this hostile political climate fostered: the Peach Blossom Spring-a secluded community in harmony with nature, self-governed, blissfully the world forgetting, by the world forgot-came to embody both the literati's nostalgia for a past that did not ostracize them, and the gardens behind whose walls they were forced to retreat.

\footnotetext{
$5^{2}$ “自云先世避秦時亂，率妻子邑人，來此絕境，不復出焉，遂與外人間隔。問今是何世乃 不知有漢, 無論魏亞,. Tao Qian, Tao Yuanming, p. 425 .

53 See Zongqi Cai, 'A historical overview of Six Dynasties aesthetics', in Zongqi Cai, ed., Chinese aesthetics: the ordering of literature, the arts, and the universe in the Six Dynasties (Honolulu, HI, 2004), pp. 1-28.

54 'Abstruse learning' (xuanxue 玄學) would become a major school of thought in Chinese philosophy from the third to the sixth century CE. Predicated upon the rejection of traditional Confucian thought, the Xuanxue school developed metaphysical interpretations of the Daoist canon (chiefly the Daodejing 道德經 and the Zhuangzi莊子), which in turn informed neo-Daoist readings of the Confucian one.
} 
This is not to deny Taohua yuan ji its relevance as utopian archetype, nor to reassert the priority of More's prototypical Utopia in the transcultural history of this idea. The composition of Taohua yuan ji is clearly informed by tropes of secluded grottos as loci of social/individual bliss and 'return to nature' ( fan ziran 返自然) narrations that share with the Morean notion of utopia a similar significatory purpose.55 As Zhang Longxi has shown, it is entirely possible to argue for Tao Yuanming's Peach Blossom Spring as an ante litteram locus of conciliation of utopia as both individual pursuit and collective endeavour, 'more than a thousand years before Thomas More and more than a thousand and three hundred years before Voltaire['s Eldorado]' $.5^{6}$ Yet, while it may be true that the principles that inform Tao Yuanming's work are 'probably more important for ethical and political philosophy than a sophisticated plan or blue print $[\mathrm{sic}]$ for an ideal society with intrusive rules, regulations, and protocols', I argue here that it is not in Taohua yuan ji that we can find the most constructive point of reference for a comparative understanding of utopia in the Chinese tradition. 57

Writing a history of utopia that relies on the contingent appearance of this idea through all linguistic, cultural, and social provinces according to criteria of mere similarity would eventually dilute it to its broadest recognizable denominator. $5^{8}$ If it is true that the historical emergence of utopianism as a modality of thinking and writing is predicated upon underlying instances of 'spatial disjunction' and 'political deterritorialization',59 then the ground for the reframing of utopia/wutuobang as the composite result of different situated co-productions must be located accordingly. Taohua yuan ji posited no disjunction: the fact that Tao Yuanming located the Peach Blossom Spring inside a grotto hidden within a forest located in what would be considered 'China proper' (Zhongguo benbu 中國本部), and that the utopian community thereby introduced was modelled after a famous passage from the canonical Laozi 老子, 60 qualifies Taohua yuan ji as a utopia of $r$-territorialization that did not posit a radically 'other' alternative, but rather called for a rectification of the present according to the past. In the case of More's Utopia (but also of Shakespeare's

55 On the recurrence of Daoist tropes in Tao Yuanming's Taohua yuan ji, see, for example, Stephen R. Bokenkamp, 'The Peach Flower Font and the Grotto Passage', Journal of the American Oriental Society, 106 (1986), pp. $65^{-77}$.

$5^{6}$ Zhang, 'Tao Qian', p. $3^{66 .}$

57 Ibid., p. 374 .

$5^{8}$ Lyman Tower Sargent tackles this question in 'Utopia: the problem of definition', Extrapolation, 16 (1975), pp. 137-48.

59 Balasopoulos, 'Suffer a sea change', p. 124.

6o 'Neighboring countries can see one another, and the crowing of roosters and the barking of dogs can be heard, but people would never associate with one another all their lives, even till death' (鄰國相望, 雞犬之聲相聞, 民至老死, 不相往來). Passage retrieved from Chinese Text Project, https://ctext.org/dao-de-jing, based on Wang Bi’s 王缅 edition. Translation by Zhang in 'Tao Qian', p. 370. 
The Tempest and Francis Bacon's New Atlantis ${ }^{61}$ ), the underlying disjunction was represented by Europe's oceanic turn after Christopher Columbus's arrival in the New World at the end of the fifteenth century - 'the most thorough transformation of the planetary outlook in all the known history of the world' and 'the first, complete, space revolution on a planetary scale'. ${ }^{2}$ Consequently, to retrace utopia as a chronotype-like marker of time manifesting itself from the 'specific site' of China's tradition, we should look for a similar instance of transformation and spatial revolution therein.

Given the revolutionary impact of the New World's incursion into the cultural geography of Renaissance Europe, the use of such a unique historical event as ground for cultural comparison is admittedly problematic. At the same time, the peculiarity of this event allows for its relatively straightforward 'typification': Europe's discovery of the New World was a watershed moment in that it ultimately changed the shape of the known and knowable world. ${ }^{6} 3$ Arguably, a similar shift in perceptions - one that embraced a truly global, networked, and multicentred perspective - was occasioned in late imperial China by the Qing's defeat in the First Opium War against Great Britain and the signing of the treaty of Nanjing in $1842 .{ }^{6}$ Though a relatively marginal conflict if measured on a global scale (the British deployed fewer than 5 ,ooo troops and twenty vessels, while the Manchu court relegated the management of the war to local militias at the provincial level ${ }^{65}$ ), this war and its immediate aftermath marked a radical change in the way that late imperial China positioned itself in the world. The subsequent implementation of the so-called Unequal Treaties system sanctioned the subordination of the Qing empire to a semicolony of the Western powers by granting the latter unprecedented sovereignty rights over the former's territory and by forcing the Manchu court to relinquish substantial authority over the management of its domestic affairs, economic and financial policies, and foreign enclaves. ${ }^{66}$ The Manchu-born stateman Qiying's 耆英 $(1787-1858)$ claim that between 1839 and 1842 'the barbarian situation has undergone deceptive changes and ... has not produced a unified

61 See Jeffrey Knapp, An empire nowhere: England, America, and literature from Utopia to The Tempest (Berkeley, CA, 1992).

62 Carl Schmitt, Land and sea (Washington, DC, 1997), p. 33.

63 The extent of this radical shift in perspectives can be understood at a glance by comparing world maps from before the discovery of the Americas (such as the map printed in Claudius Ptolemy's Geographia from 1482) and after (such as Martin Waldseemüller's Universalis cosmographia wall map from 1507$)$.

64 On the causes, development, and aftermath of the First Opium War, see, for example, Peter Ward Fay, The Opium War, I840-I 842 : barbarians in the Celestial Empire in the early part of the nineteenth century and the war by which they forced her gates ajar (Chapel Hill, NC, 20oo); and Julia Lovell, The Opium War: drugs, dreams and the making of China (London, 2011 ).

65 See James Polachek, The inner opium war (Cambridge, MA, 1992), pp. 169-71.

66 For a useful overview of the implications of fin de siècle China's condition of semi-coloniality, see Jürgen Osterhammel, 'Semi-colonialism and informal empire in twentieth-century China: towards a framework of analysis', in Wolfgang J. Mommsen and Jürgen Osterhammel, eds., Imperialism and after: continuities and discontinuities (London, 1986), pp. 290-314. 
development', and that as such it required that 'the methods by which to conciliate the barbarians ... change their form' was, if anything, a colossal, etiquette-hindered understatement, in that his signing of the treaty of Nanjing de facto recognized the inadequacy of the variety of practices (trade agreements, diplomatic negotiations, and localized military interventions) through which the Chinese empire had been regulating its foreign affairs. ${ }^{67}$

On a symbolic level, this shift resonated deeply. The displacement of the Manchu court from its hegemonic position implied the redefinition of the epistemological co-ordinates through which it traditionally defined its position in the world. If, during the early stages of this confrontation, the Chinese literati were able to rationalize their country's perceived incapacity to assert itself in the world at large as a purely instrumental question of technical and military prowess, the ti-yong 體用 conceptual safeguard to which this position was anchored gradually grew untenable. ${ }^{68}$ As the compound debacle of the Second Opium War, the near-disaster of the Taiping Rebellion, and the wake of insurgencies and rebellions that followed further weakened China's position during the second half of the nineteenth century, the recognition of Western power engendered a compulsive attempt at 'self-strengthening' (ziqiang 自強), which conversely exposed the central government's reticence to reform. Finally, as the Chinese again lost face at the hands of the Japanese over the control of the Korean peninsula in 1895 , the conservatism of the early reformers gave way to a new wave of radical reformists who saw in the complete Westernization of the country's institutional apparatus the only way out of the colonial impasse. ${ }^{69}$

67 Although traditional scholarship, following John K. Fairbank's example, has long referred to these practices as a 'tribute system', no distinct institution or 'system' was in place, but rather a series of practices informed by a shared set of guiding principles, implemented according to the specificities of a given context. For an overview of these practices, see Ji-Young Lee, China's hegemony: four hundred years of East Asian domination (New York, NY, 2017), pp. 27-55. On the notion of 'tribute system', see Henrietta Harrison, 'The Qianlong emperor's letter to George III and the early-twentieth-century origins of ideas about traditional China's foreign relations', American Historical Review, 122 (2017), pp. 680-701. On the persistence of this model in recent scholarship, see Peter Perdue, 'The tenacious tributary system', Journal of Contemporary China, 24 (2015), pp. 1002-14.

68 On the notion of ti-yong 體用 as 'Zhongxue wei ti, xixue wei yong’ 中學為體, 西學為用 ('Chinese learning as essence, Western learning for practical use') in late imperial China's discourse of reform, see Joseph R. Levenson, Confucian China and its modern fate: a trilogy ( 3 vols., Berkeley, CA, 1968), I, pp. 59-78.

69 As Joachim Kurtz remarked concerning the construction of the notion of 'middle ages' in Chinese historiography, the late Qing reformer Liang Qichao 梁啟超 articulated China's transition from antiquity to modernity as an experience of rupture and de-territorialization. In his 1901 essay 'Prolegomena to a history of China' ('Zhongguoshi xulun' 中國史敘論), Liang framed China's modern turn as a transition from a 'Chinese China' ('Zhongguo zhi Zhongguo' 中國之中國), 'a period in which the Chinese nation had developed, competed and associated only among themselves', to a 'global China' ('Shijie zhi Zhongguo' 世界之中國), 'an age in which the Chinese nation united all Asian peoples in order to jointly interact and 
The idea of utopia as a twofold discourse of disjunction (for which the utopian discourse foregrounds a new historical consciousness in the making) and emplacement (for which its contingent reality is historicized) emerged from this background. In fact, one of the most recognizable traits that characterized the early modernity of Chinese literature (jindai wenxue 近代文學) was the coalescence of an overtly utopian imaginary that intertwined the form of


novelists from this period elaborated and resolved the condition of uncertainty of late imperial China's ongoing process of social, political, and cultural readjustment via its utopian negation in the literary text. Such a rhetorical project seems at least to link a variety of novels written at the turn of centurysuch as, among others, Xin Zhongguo weilai ji 新中國未來記 (Future chronicles of New China, 1902), Huangren shijie 黄人世界 (Yellow man's world, 1903), Shizi hou 獅子吼 (The lion's roar, 1905), Wutuobang youji 烏托邦遊記 (Travel to Utopia, 1906), Xian zhi hun 憲之魂 (The spirit of the constitution, 1907), Xin jiyuan 新紀元 (The new era, 1908), Guangxu wannian 光緒萬年 (The ten thousand years of the Guangxu reign, 1908), Dian shijie 電世界 (Electric world, 1909), and Xin Zhongguo 新中國 (New China, 1910) - in what unfolds as a veritable utopian negative of fin de siècle China in a moment of radical transition..$^{11}$ Among the variety of utopian texts that punctuated the literary landscape of fin de siecle China, almost as if foregrounding its dissolution via its parodic idealization, one particular novel stands out as epitome of the utopian genre in the local Chinese variety: Wu Jianren's 吳趼人 Xin Shitou ji 新石頭記 (The new story of the stone). Serialized between 1905 and 1906 in the pages of Nanfang bao 南方報 (The Southern Gazette), and published in volume format by Shanghai-based Gailiang xiaoshuo she 改良小說社 in 19o8, Xin Shitou ji represents one of the most telling utopian specimens of its time.

Amid Wu Jianren's vast and eclectic literary production, Xin Shitou $j i$ is often overlooked. A prolific journalist and novelist, $\mathrm{Wu}$ is most often remembered for novels such as Henhai 恨海 (The sea of regret), Ershi nian mudu zhi guai xianzhuang 二十年目睹之怪現狀 (Bizarre happenings eye-witnessed over two decades), and Jiuming qiyuan 九命奇冤 (The strange case of nine murders), or his eccentric collection of grievances, Wu Jianren ku 吳趼人哭 (Wu Jianren cries). Yet, whereas these works indulge in the mannerist narration of wails and denouncements that was typical of much of the literary production of jindai, Xin Shitou ji maintains a carnivalesque appeal that sets it apart as a one-of-a-kind work of fiction whose

compete with Western powers'. Joachim Kurtz, 'Chinese dreams of the middle ages: nostalgia, utopia, propaganda', Medieval History Journal, 21 (2018), pp. 1-24.

$7^{\circ}$ Concerning the definition of jindai, see David Der-wei Wang, 'How modern was early modern Chinese literature? On the origins of "jindai wenxue", Chinese Literature: Essays, Articles, Reviews (CLEAR), 30 (2008), pp. 145-65.

${ }^{71}$ For a general overview of the authors and texts mentioned here, see Guo Jiang 郭蓁, 'Lun wan Qing zhengzhi wuotuobang xiaoshuo’ 論晚清政治烏托邦小說 ('On the political and utopian novels of the late Qing'), Qing mo xiaoshuo, 22 (1999), pp. 53-86. 
features eschew univocal modalities of interpretation and branch out to other spaces and times.

In Xin Shitou ji, Thomas More's prototypical utopia finds a proper counterpoint. Considered together, these two works of fiction mark the long gestation of a notion of colonial modernity whose 'general law' is one of displacement, deterritorialization, and semiotic rupture. Like More's Utopia, Xin Shitou jis chronotope is twofold, in that the forty chapters that compose this novel are divided into two acts of equal length: the first, a series of vignettes on fin de siècle China; the second, a lengthy account of the so-called 'civilized country' (wenming guo 文明國) or 'civilized world' (wenming shijie 文明世界). The linkage between the old world of late imperial China and the mundus novus depicted in the text is given by the novel's hero, a reborn Raphael Hythloday in the guise of Hong lou meng's 紅樓夢 protagonist Jia Baoyu 賈寶玉 - a quintessential liminal figure in the canon of traditional Chinese literature. ${ }^{2}$

Wu Jianren's Xin Shitou ji shares a significatory purpose with More's Utopia, in that both texts translate to the figural domain the contingent instances of cultural fragmentation and upheaval that constitute the historical preconditions for utopian thinking to manifest itself. The rupture brought forward by old Europe's maritime displacement is allegorized in More by the separation of the island of Utopia from the known world; the rupture of late imperial China's traditional worldview by means of unequal international treaties is in turn allegorized by the positing of a 'civilized world' that unfolds beyond the self/other colonial dichotomy:

Our country has a total of two million districts, each one of them has an area of one hundred square $l i$. It is divided into five regions: east, west, south, north, and centre. Each region comprises four hundred thousand districts, and each district is identified according to a particular symbol and a number from one to one hundred thousand. As for the symbols, the central districts are divided into $L i$ 禮, $L e$ 樂, Wen 文, and Zhang 章; the eastern districts are divided into Ren 仁, Yi 義, $L i$ 禮, and Zhi 智; the south is divided into You 友, $C i$ 慈, Gong 恭, and Xin 信; the west is divided into Gang 剛, Qiang 強, Yong 勇, and $Y i$ 毅; and the north into Zhong 忠, Xiao 孝, Lian 廉, and Jie 節. Here we are in the hundredth district of the Qiang province, so we call this particular district 'The hundredth Qiang'.73

$7^{2}$ The character of Jia Baoyu, 'precious jade', comes from Cao Xueqin's 曹雪芹 masterpiece Hong lou meng 紅樓夢 (Dream of the red chamber) (also known as Shitou ji 石頭記 or The story of the stone, hence Xin Shitou ji 新石頭記 as The new story of the stone) and maintains strong symbolic value in both novels. According to the lore, Jia Baoyu is the personification of the only stone that was cast aside by the goddess Nü Wa 女嗗 after the restoration of the vault of heaven. The stone thus acquired the shape of a man, Jia Baoyu, but, because he was left aside from the creation of the world, he gained the ability to observe it from the outside.

73 “粉境共是二百萬區, 每區一百方裡, 分東西南北中五大部。每部統轄四十萬區, 每區用 一個字作符識。從一至十萬, 編成號數。那作符號的字, 中央是『禮、樂、文、章』四十 字; 東方是『仁、義、禮、智』四個字; 南方是『友、慈、恭、信』四個字; 西方是『剛、

強、勇、毅』四個字; 北方是『忠、孝、廉、節』四個字。現在這裡, 便是強字第一百區, 我 
By reassessing a 'centre' (zhong) beyond the centre of China proper, Wu Jianren purposefully rejects the position of marginality imposed by the European powers upon fin de siècle China. Yet beyond Wu's apparent gesture of revanchist reversal lies something more: the radical potential of the idea of utopia itself. A careful look at the geography of the 'civilized country' presented in Xin Shitou ji quickly reveals the wider scope of Wu Jianren's utopian project. If it is really true that Xin Shitou jïs 'civilized world' has 'two million districts', and that each district has an area of one hundred square $l i$ (fifty square kilometres), then its area would extend for a total of 100 million square kilometres - almost as much as the entire inhabitable world.74 In other words, Wu's utopian vision would encompass the whole of humanity, thus reaffirming the idea and ideal of utopia as a truly transcultural goal, although one that is always informed by the ideological tenets of the part that posits it.

This brings us back to Yan Fu's translation of Huxley's Evolution and ethics, and the invention of wutuobang at the turn of the twentieth century. A fundamental discrepancy marks the rendition of Evolution and ethics into classical Chinese: despite Yan Fu's claims of 'faithfulness' (xin 信) to the original text as one of the main principles of his translation, his work on Huxley's text was informed by 'unfaithful' motives. While Huxley insisted on the moral nature of man and the importance of ethics to counter-balance the 'might is right' claims of social Darwinism in the Spencerian mould, Yan Fu used Huxley's text to mount a defence of Herbert Spencer and his argument in favour of 'the implications of Darwinian principles for the sphere of human action'.75 If, for Huxley, what made the 'garden of Eden' utopian was its capacity to keep the laws of Darwinian evolution at bay by allowing the intrinsically moral nature of the human race to flourish, for $\mathrm{Yan} \mathrm{Fu}$ - we must infer - utopia as wutuobang was ultimately something else. In his Neo-Confucian willingness to attribute the sources of morality and reason to heaven and not, like Huxley, to humanity lies perhaps a vision of utopia that stems from and is inscribed in the former and not dependent on the fickleness of the latter. It is, I argue, upon such truly idealistic principles that a genuinely transcultural understanding of the idea of utopia ought to establish its grounds.

們省稱, 只叫『強一百』'. Wu Jianren 吳趼人, Xin Shitou ji 新石頭記 (Zhengzhou, 1986), p. 172.

74 The world's surface amounts to $5^{10,0} 7_{2}$ million $\mathrm{km}^{2}$, 70.9 per cent (c. $3^{61}$ million $\mathrm{km}^{2}$ ) of it being water and the remaining 29.1 per cent (c. 148 million $\left.\mathrm{km}^{2}\right)$ land. Deserts make up one-third of the land's surface area, thus leaving us with approximately 100 million $\mathrm{km}^{2}$ of inhabitable land.

75 Schwartz, In search of wealth, p. $9^{8}$. 